\title{
Çeviri: Yunanperest Çılgınlık ve Helenseverlik
}

\author{
Çev. Şaban BIYIKLI*
}

18. yüzyıldan itibaren Avrupa'da, antik Yunan araştırmalarının hazırladığ1 zeminde giderek gelişen bir Yunanistan heves ve heyecanı ortaya çıkmıştır. $\mathrm{Bu}$ coşku, klasizm ve neoklasizm olarak anılan sanat ve edebiyat akımlarında kendini göstermiştir. Çağdaş kültürün temelleri antik Yunan kültüründe aranmış; bu kadim kültür daha fazla tanınmaya, hatta canlandırılmaya çalışılmıştır. Bu girişimler, edebî ve sanatsal formlar, motifler ve temalarla kendini dişavurmuştur. Öte yandan Avrupa Helenseverliği (Philhellenism), politik sahada da etkili olmuştur. Yunan Bağımsızlık Savaşı sırasında müstakil Yunanistan davasını destekleyen sayısız cemiyet kurulmuş; Osmanlı İmparatorluğuna karşı savaşmak için Yunanistan'a gönüllüler gitmiştir. Buna karşılık Yunanistan'da Aydınlanmanın doğuşu da varlığını en azından kısmen, Avrupa üniversitelerinde eğitim görüp Aydınlanma fikirlerini Yunanistan'a getiren bu Yunanlı talebelere borçludur.

\section{Avrupa'da Edebî ve Popüler Helenseverlik}

18 ve 19. yüzyıllardaki yeni hümanizmin Avrupa'da Helenseverlik ${ }^{1}$ ikliminin oluşmasında önemli bir payı vardır. Bu yeni hareket, Yunan sanatının estetik idealleri ve etik normların tespit eden Johann Joachim Winckelmann (17171768) tarafindan kurulmuştur. Geschichte der Kunst des Altertums (Antik Çağın Sanat Tarihi) (1764) adlı eserinde Winckelmann, Antik Yunan'1 estetize olmuş bir sanat ve kültür tarihinin başlangıç noktası olarak almıştır. Winckelmann'ın şu sözleri, onun düsturunu yansıtmaktadır:

\footnotetext{
* Marmara Üniversitesi SBE Doktora Öğrencisi

Elmek: sabanbiyikli@gmail.com

1 1989-2010 yılları arasında yazar, Avrupa'da ve dünya genelindeki Yunanseverliğin çeşitli yönleri ve tezahürleriyle ilgili olarak Philhellenische Studien adlı 15 ciltlik bir eser yayınlamıştır. İlk cildin editörlügünü Ursula Wiedenmann, 15. cildin editörlüğünü ise Konstadinos Maras ve Heinrich Scholler ile birlikte yapmıştır.
} 
Der einzige Weg für uns groß, ja wenn es möglich ist, unnachahmlich zu werden, ist die Nachahmung der Alten, und was jemand von Homer gesagt, daß derjenige ihn bewundern lernet, der ihn wohl verstehen gelernet, gilt auch von den Kunstwerken der Alten, sonderlich der Griechen. ${ }^{2}$

Sonradan Friedrich von Schlegel (1772-1829), "aramızda akılcı bir ahlâk sezgisine sahip olan ilk kişi, ilahi esinle Antik Çağda ve antik sanat formlarındaki mükemmel insan modelinin varlığını sezen ve bunu duyuran Rahip Winckelmann'd ${ }^{\prime \prime}{ }^{3}$ diyecektir.

1800'lerin başlarında yeni hümanist edebiyat -Goethe'nin Iphigenia Tauris 'unda "[kederli bir ruhla] Grek yurdunu arayan" Iphigenia gibi" - eski Yunan edebiyatını, bilhassa da sanatını ulaşılmaz bir estetik ideal olarak telakki ediyordu. Avrupalılar bütün Batı kültürünün temellerini antik Yunan kültüründe görüyordu. Bu nedenle "hakiki insanlığın zirvesi” olarak gördükleri “antik Yunan insanının" (idealleştirdikleri) yaşama tarzında kendi ahlâkî pusulalarını buluyorlard1. ${ }^{5}$ Her şeyden önce estetik ve kültürel-tarihsel bir mahiyete sahip olan bu "Yunan antikitesinin keşfi”, bilahare Avrupalıların çağdaş Yunanlıları kendi "ataları" ile bir tutmasına hizmet etmiştir. Karl Mendelssohn-Bartholdy'nin (1838-1897) "althellenische Mode" (antik Yunan modası) dediği, Alman oyun yazarı Julius von Voss'un (1768-1832) aynı adlı piyesinde "Griechheit" (Yunanlılı) diye alay ettiği bu antik Yunan coşkusu, Avrupa genelinde Yunanperestler (Hellenists) ile HelenseverlerinYunanistan'a ilgi ve Yunanlılara karşı sempati teşvik eden bir hareketi başlatmasına önemli bir dayanak sağladı.

$\mathrm{Bu}$ yeni hümanizm ve klasizm döneminde Almanya'da önemli Yunanca elyazmaları yayınlanmış; klasik filoloji, felsefe, arkeoloji ve sanat tarihi gelişme göstermiştir. Kadim Yunan dili ve edebiyatı ile antik vezin şekilleri Almanya'da büyük bir hevesle incelenmiş ve bu incelemeler, Alman edebiyatının ilerlemesine büyük katkıda bulunmuştur. Yunanlıların altı tef'ileli veznini [heksametron] kul-

\footnotetext{
2 Winckelmann, Gedanken 1756, s. 3. ("Büyük ve - eğer mümkünse - taklit edilemez olabilmemizin tek yolu eskileri taklit etmektir. Homeros hakkında söylenen "Ona hayran olmayı öğrenen, onu anlamayı da öğrenmiştir" sözü kadim insanların ve bilhassa Yunanlıların sanat eserleri için de geçerlidir", İngilizce tercüme: Niall Williams [N.W.]) Bu konuda ayrıca bk. Seidl, Das Land der Griechen 1989, s. 22.

3 Akt. Beiser, Political Writings 1999, s. 134.

4 Goethe, Iphigenia in Tauris 1851, s. 1.

5 Pfeiffer, Studien 1968, s. 223 (“Gipfel alles echten Menschentums”, “Alten”, İng. terc. N. W.).

6 Bu oyun ilk kez 1807'de Berlin'de sahnelenmiştir. Bk. Quack-Eustathiades, Philhellenismus 1984, s. 21.
} 
lanmak suretiyle Alman şiirine yeni açılımlar getiren Friedrich Gottlieb Klopstock (1724-1803), Messias adlı eserinde bu antik vezin yoluyla Alman şiir dilinin özgün bir ifade biçimini yaratmayı başarmıştır.

Üç büyük Alman şairi olan Johann Wolfgang von Goethe (1749-1832), Friedrich von Schiller (1759-1805) ve Friedrich Hölderlin (1770-1843), Almanya'da yaşayıp Almanya' da yazmakla beraber, şiir muhayyilelerinin ağırlık merkezi Yunanistan olan şairlerdi. Bu şairler, Yunanistan'a ayak basmadıklarından antik Yunan'1 ve kültürünü idealize edebiliyorlard. Hölderlin'in romanına adını veren Hyperion, 1770'de Osmanlı İmparatorluğuna karşı patlak veren fakat büyük bir şiddetle bastırılan Yunan isyanı sırasında Mistra'ya ulaşıyordu. Böylelikle Hölderlin, Rumların siyasi özgürlük arzularına canlı bir kanıt yaratmış oluyordu. Wilhelm Heinse'nin (1749-1803) yazdığı ve kahramanlarının Osmanlı egemenliğine son vermek üzere Yanya'ya seyahat ettiği Ardinghello, Künstlerroman (bir sanatçının olgunluğa ermesine dair bir anlatı) adlı eserinde de aynı arzu dile getirilmektedir.

Yunanistan'ın ve kültürünün böylesine romantikleştirilmesi, eserleriyle tüm Avrupa'da Helensever bir iklim yaratan Victor Hugo (1802-1885), FrançoisRené Vicomte de Chateaubriand (1768-1848), Percy Bysshe Shelley (17921822) ve Santarosa Kontu Annibale Santorre dei Rossi di Pomarolo (17831825) gibi başka Avrupalı yazarlarda da görülmektedir.

17. yüzylldan itibaren Yunanistan'a seyahat eden Avrupalılar da Helenseverliğe zemin hazırlamıştır. Bu seyyahların esas amacı antik Yunan'ı, yani klasik edebiyat incelemeleriyle ve İtalya'daki antik kentlere düzenledikleri "Büyük Gezilerle" (Grand Tours) gerçekleştirmeye çalıştıkları bir rüyayı keşfetmekti. 18. yüzyılda Avrupalı seçkinler, Osmanlı İmparatorluğu'nun parçası olan Yunanistan'a gitmek imkânsız değilse de zor olduğundan dolay1, Yunan kültürünü Roma kültürünün prizması aracıllğıyla görüyordu. Bu dönemde ancak birkaç Avrupalı, antik Yunan kentlerine yolculuk etmeyi başarabilmişti. Bu seyahati yapanlar da ister istemez Yunanistan'ın çağdaş halkının durumuna dair fikirler edinmiş ve mülahazalarda bulunmuştur.

Edebî Helenseverliğin izleri, Avrupa'nın en kuzeyinde, örneğin Finlandiya ve İsveç’te dahi görülmektedir. Önceleri bu gelişmede Finli öğrenciler önemli rol oynamış ve bunlardan bazılarına antik Yunan edebiyatını tanıtan kimse Martin Cru- 
sius (1526-1607) olmuştu. Bu öğrenciler, Yunan dili ve edebiyatına duydukları hayranlı̆̆ ifade eden Helensever şiirler yazmış ve okudukları antik Yunan metinlerini büyük bir coşkuyla taklide girişmiş̧i. Finlandiya'da erken döneme ait edebî Helenseverliğin en önemli kanıt1, Johan Paulinus Lillienstedt'in (1655-1732), 1678'de Uppsala' da ${ }^{7}$ yaptı̆̆ Magnus Principatus Finlandia adlı konuşmasıydı.

Yunan dili ve edebiyatı, hayranlık duyulduğu 18. yüzyıl Rusya'sında da teşvik görüyordu. Batı Avrupa tarzı eğitimden geçen I. Petro (1672-1725) ve II. Katerina (1729-1796), Rusya'da edebî Helenseverliği teşvik etmişlerdir. Ömrünü Yunan edebiyatı incelemelerine adayan 18. yüzyılın büyük Yunanlı bilgini Eugenios Voulgaris (1716-1806), II. Katerina'nın sarayında etkindi. Yunan Aydınlanmasına katk1 sağlayan en önemli isimlerden biri olan Voulgaris, Voltaire (1694-1778) ve başka yazarları Yunancaya tercüme etmişti. II. Katerina'nın emriyle Voulgaris, Çariçenin kanunların kodifikasyonuna dair yol gösterici ilkelerini kaydeden Nakaz'ını (Talimat) Rusça'dan Yunancaya tercüme etti. Rus Çariçesi 1775 'te St. Petersburg'da Yunan çocukları için bir Yunan jimnaziyası (gimnasiia=lise) dahi yaptırmıştır. Rusların Yunanlılara duyduğu sempati edebî Helenseverliği aşarak fiiliyata geçmiş ve Yunanistan'a faal politik destekle neticelenmiştir. Rus Orlov kardeşlerin Osmanlılara karşı Mora'da başlattıkları Yunan isyanı ile (1770) zirveye ulaşan Rus politik Helenseverliğinde iki ulusun da Ortodoks inancını paylaşması kuşkusuz çok önemli bir rol oynamıştır. ${ }^{8}$

\section{Avrupalı Seyyahlar ve Yunanistan'a Seyahat Anlatıları}

17. yüzyıldan itibaren Yunanistan'1 ziyaret eden Avrupalı seyyahlar, öncelikli olarak antik Yunanla ilgileniyorlardı. Bununla birlikte bu seyyahlar, antik kentlere yaptıkları ziyaretler sayesinde Yunanlı çağdaşlarının yaşama şartlarını da tanıma imkânı bulmuştu. Sanatsal ve mimari kalıntılara olabildiğine hayranlık duyan bu seyyahlar, bir yandan da uluslarının o parlak geçmişinden ellerinde hiçbir şey kalmamış gibi görünen modern Yunanlıların sefalet ve eğitimsizliğini de anlatıyordu. Bu Yunanistan imaj1, Pierre Augustin Guys (1721-1799) Voyage littéraire de la Grèce (Yunanistan'da Edebî Seyahatler) adlı eserini neşredene kadar (1771) değişmemiştir. Guys, Yunanlı çağdaşlarını meşhur atalarının halefleri olarak gören

7 Erken dönem Fin yunanseverliği hakkında bk. Korhonen, Philhellenismus 2007.

8 18. yüzyıldaki Rus Yunanseverliğine dair ayrıntılı bir tartışma için bk. Arsh, Russian State Philhellenism 2007; Kitromilides, Eugenios Voulgaris' in Siyasi Görüşleri 2003 (Yunanca). 
ilk Avrupalı seyyah olmuştu. Bu seyahatname, Yunanistan'ın geleceği açısından hassas bir dönemde yayınlanmıştı. Osmanlı hakimiyetine yönelik, yukarıda anılan 1770'deki Rum isyanı, büyük bir güçle bastırılmıştı. Guys, şimdi Yunanlıları, meşru bir özgürlük kampanyası yürüten Hıristiyan bir ulus olarak resmediyordu.

1788 yılına gelindiğinde Başkeşiş Jean-Jacques Barthélemy'nin (1716-1795) Voyage du Jeune Anacharsis en Grèce (Genç Anacharsis'in Yunanistan Seyahati) adlı romanı Paris'te dolaşımdaydı. MÖ 4. yüzyılda Anacharsis adlı genç bir İskit'in Yunanistan seyahatine dair kurgusal bir anlatı olan bu eser, bol miktarda bilimsel ayrıntılarla dikkati çekiyor ve diğergâm bir Helenseverliği teşvik ediyordu. Birkaç yıl sonra, o dönemde Dersaadet'te Fransız sefiri olarak görev yapan Marie-GabrielFlorent-Auguste de Choiseul-Gouffier (1752-1817) bu kitab1, Yunanistan ziyaretinde bir tür seyahat rehberi olarak kullanmıştır. Choiseul-Gouffier kendi araştırmalarına dayanarak Voyage Pittoresque de la Grèce'ini (Şâyân-1 Tasvir Yunanistan Seyahati) derledi. Arkeolojik malumata geniş yer veren ve aynı zamanda çağdaş Yunan hayatına dair yazarın şahsi gözlemlerini de içeren bu derleme, 1782-1822 yılları arasında birkaç cilt hâlinde basılmıştır. Benzer şekilde Jean-Michel Moreau (1741-1814) ve Jean-Baptiste Hilaire (doğ. 1753) gibi ünlü çağdaş sanatçlların bu çalışma için yarattığı illüstrasyonlar, antik Yunan mimari ve sanatsal kalıntılarına ilişkin çalışmaları teşvik etmekle kalmamış; Avrupalıların, Osmanlı idaresi altında yaşayan Hıristiyanlara duydukları sempatiyi de arttırmıştır.

Avrupa'nın Yunanistan çoşkusu, 19. yüzyıl başlarında zirveye ulaştı. Fransız Devrimi ve Avrupa Aydınlanması, siyasi atmosferi Yunanistan lehine değiştirdi. Avrupa devletleri artık, Yunanistan'a, ülkenin şartlarını ayrıntısıyla araştırmak üzere diplomatlar ve politik misyonlarla memurlar gönderiyordu. Bu seyyahlar, Yunanlıların ekonomik ve eğitim şartlarının tedricen iyileştiğini kaydediyor, fakat bunun yanında Osmanlı makamlarının keyfî idaresini ve Rum halka karşı işlenen zulümleri de rapor ediyordu.

Arkeolojik araştırmalar da 19. yüzyıl başlarında Helenseverliğin yayılmasında önemli bir rol oynamıştı. Örneğin, İngiliz Albay Martin William Leake (17771860), 1804-1811 yılları arasında hükümeti adına siyasi ve askerî istihbarat toplamak üzere gizli politik görevle Yunanistan'1 dolaşmıştır. Bu esnada da kendisini büyük bir iştiyakla arkeolojik ve topografik araştırmalara adamıştı. Aldığı klasik 
eğitim ile antik ve modern Yunanca bilgisi sayesinde yazar, ziyaret ettiği bütün mekânları bilimsel bir kesinlikle tasvir edebilmiştir. Aynı dönemde İrlandalı arkeo$\log$ ve illüstratör Edward Dodwell (1767-1832), İskoç mimar ve topograf Sir William Gell (1777-1836) ve ressam Simone Pomardi (1760-1830) ile birlikte Atina'ya seyahat etmiştir. Dodwell'in A Classical and Topographical Tour in Greece During the Years 1801, 1805 and 1806 (1801, 1895 ve 1806 Ylllarinda Klasik ve Topografik Yunanistan Gezisi) adlı eseri ve Views in Greece (Yunanistan Manzaraları) adlı güzel albümü Yunanistan'ın geçmişi için çok değerli kaynaklardır.

Yunanistan'a giden ve ortaya koydukları tasvir ve çizimlerle Avrupa'da Helenseverliğin doğuşuna katkıda bulunan seyyah ve araştırmacıların listesi oldukça uzundur. Nürnbergli soylu bir aileden gelen Carl Haller von Hallerstein'1n (17741817) 1810 'da Yunanistan'a gelmesi, Yunanistan'ın geçmişine yönelik arkeolojik çalışmalar açısından uzun süre önemini korumuştur. Bir süre Delphi ve Korint'te vakit geçiren Hallerstein, ardından Atina'ya gitmiş ve burada İngiliz mimarlar Charles Robert Cockerell (1788-1863) ve John Foster (tahm. 1787-1846) ile tanışmıştır. Bu üçlü Acropolis, Sounion ve Yunanistan'ın başka sitelerinde çizimler yapmıştır. Fakat Hallerstein'ın kendisine ün kazandıran en önemli çalışması, Aegina [Egine] Adasındaki Aphaia Tapınă̆ı'nda gerçekleştirdiği kazılar olmuştur. Arkadaşları Cockerell, Jacob Linkh (1787-1841) ve Foster'la birlikte, kalıntıları bugün Münih'deki Glyptothek'te* sergilenen Jupiter Panhellenion Tapınağı'nın incelenmesi ve ortaya çıkarılmasına özel önem vermiştir. Hallerstein Olympia'daki çalışmalarından sonra Kasım 1811'de Bassae'deki Apollon Epikourios için inşa edilmiş olan Tapınağı inceleyip planını çıkarmaya girişti.

Hallerstein'ın grubuna katılarak bu Tapınaktaki inceleme vekazı çalışmalarına iştirak eden Otto Magnus von Stackelberg (1787-1837), daha sonra Der Apollon Tempel zu Bassae in Arkadien und die daselbst ausgegrabenen Bildwerke (Arkadia Bassae'deki Apollon Tapınağı ve Burada Gün Yüzüne Çıkarılan Duvar Resimleri) başlıklı abidevi eserini yazmıştır. Bu eser, dönemin arkeolojik araştırmalarının zirvesini teşkil etmektedir. Stackelberg'in 1834'te yaymlanan La Grèce: Vues Pittoresques et Topographiques (Yunanistan: Şâyân-ı Tasvir ve Topografik Manzaralar)

\footnotetext{
" Glypothek Müzesi, Bavyera Kralı I. Ludwig tarafından antik Yunan ve Roma dönemine ait heykellere ev sahipliği yapmak üzere 1816-1830 yılları arasında neoklasik tarzda inşa ettirilmiştir. Müze sonradan Münih’te inşa edilen 16 müze ile 40 galeriyle birlikte bugün 66 hektarlık büyüklüğe ulaşan Kunstareal (sanat semti) adlı külliyenin parçasıdır (çn)
} 
adlı albümü de çağdaş Yunan hayatına ilişkin değerli bilgiler vermektedir. Yunan Bağımsızlık Savaşının patlak vermesinden kısa bir süre önce Yunanistan'a ilişkin seyahat edebiyatı yeni bir atılım yaşamış; bu canlanmada neohümanizm, klasizm ve romantizm adlı edebî ve entelektüel hareketler de etkili olmuştur.

\section{Yunan Aydınlanması}

Batı Avrupa' daki bu akademik ve edebî Helenseverlik, Yunanlılar arasında da ulus bilincinin uyanmasına katkıda bulunmuştur. Fransız Aydınlanmacı fikirlerin ülkede giderek artan tesiri de bunda rol oynamıştır. Yurt dışında yaşayan Yunanlı entelektüeller, Aydınlanma döneminin önemli eserlerini Yunancaya çevirerek eğitimli yurttaşlarına sundular. Bunların sonradan ilham aldıkları Fransız Devriminin idealleri; bireyin özgürlüğü ve entelektüel yeteneklerinin gelişimine dair klasik kavramlara tekabül eden ilkelere dayanıyordu. Bu yeni çağın öne çıkan şahsiyetleri arasında Adamantios Korais (1748-1833), Rigas Velestinlis (17571798) ve Demetrios Kantartzis-Photiadis (1730-1800) gibi isimler yer alıyordu. Bunlar Fransızcadan yaptıkları çok sayıda tercüme ve telif yazılarıyla modern Yunan Aydınlanmasının temellerini attılar.

Atina'da Dionysios Pyrros (1774-1853) adlı bir öğretmen, 1813 y1lında okulunda düzenlediği bir törende öğrencilerine antik Yunan isimleri vermişti. Törende birer defne ve zeytin dalı takdim ettiği her öğrencisinin adının artık İoannis veya Pavlos olarak değil Perikles, Themistokles vb. olacağını ilan etti. ${ }^{9}$ Şu var ki Yunan aydınlanmasının nihai hedefi, şair ve devrimci Rigas Velestinlis örneğinin gösterdiği gibi politikti; yani Osmanlı hakimiyetine karşı ulusal bir isyana zemin hazırlamaktı.

1813'de Atina'da kurulan “İlham Perileri Dostları” cemiyeti (Philomousos Etaireia), çağdaş Yunanlıların kadim atalarına yönelik tutumlarının belirlenmesinde önemli bir rolü olmuştur. ${ }^{10}$ Carl Haller von Hallerstein, Cockerell, Peter-Oluf Brøndtstedt (1780-1842), Forster, Linkh ve von Stackelberg'in merkezinde olduğu bir arkadaş topluluğu, iki yıl önce zaten XENEION adlı bir dernek kurmuşlardı. Bu derneğin üyelik şartları şunlardı:

Jeder würdige Mann aus jedem Land, jeder Religion und jeden Alters kann

9 Bu konuda bk. Demaras, Modern Yunan Aydinlanması 1980, s. 59, (Yunanca).

10 Krş. Gründungsakt der Gesellschaft der Musenfreunde in Wien 1814, s. 79-103; Koukkou, Kapodistrias 1958, s. 37 vd. (Yunanca); Arnold, Philhellenismus 1896, s. 176; Irmscher, Der Dessauer Dichter 1968, s. 54-55. 
danach streben, XENEIOS zu werden. Die einzige grundlegende Eigenschaft, die er besitzen muss, ist die Begeisterung für Griechenland, für die Literatur, für die schönen Künste der Alten. ${ }^{11}$

İlham Perileri Dostları'nın ilk başkanı Korfulu Kont İoannis Antonios Kapodistrias (1776-1831) idi. 1814'ten sonra derneğin Viyana'da faal bir şubesi kuruldu. Derneğin esas hedefleri, Yunanlılara Antik Çağın entelektüel mirasını aktarmak, eğitim sistemini yeniden düzenlemek ve sanat hazinelerini bazı Avrupalı "Helenseverlerin” yağmasından korumaktı. Derneğin Viyana şubesine akademisyen ve edebiyatçıların yanı sıra bakanlar ve prensler de katıldı. Şube, Alman üniversitelerinde öğrenim gören Yunanlı öğrencilere de destek veriyordu. Bu öğrenciler, Goethe'nin deyişiyle "de $[m]$ Wunsch sich besonders deutsche Bildung anzueignen", ve "das Verlangen allen solchen Gewinn dereinst zur Aufklärung, zum Heil ihres Vaterlandes zu verwenden" yolunda teşvik edildiler. ${ }^{12} \mathrm{Bu}$ öğrencilerden biri olan İoannis Papadopoulos (ö. 1819), 1817-1818 yılları arasında dernekten aldığı bursla Jena' da eğitim görmüş ve aynı dönemde birkaç kez Goethe ile görüşmüş, hatta onun Iphigenie auf Tauris'ini 1818'de Yunancaya tercüme etmişti. ${ }^{13}$

Philiki Etaireia da bu bağlamda anılmalıdır. 1814'de Odessa'da Yunanlı tüccarlarca kurulan bu gizli cemiyetin yapılanması, Hür Masonlarınkine benziyordu. Philiki Etaireia'nın temel hedefi, yalnız Osmanlı hakimiyetine karşı bir Yunan isyanı hazırlamak ve uygulamaya koymakla sınırlı değildi. Rusya'nın yardımıyla Balkanların tamamında bir isyan amaçlanıyordu. Bu gizli cemiyetin önemli üyeleri arasında Patmoslu Emmanuel Xanthos (1772-1852), Artalı Nikolaos Skouphas ve Yanyalı Athanasios Tsakalof bulunuyordu. ${ }^{14}$

11 Bu konuda bk. Wünsche, Hallerstein 2003, s. 233 ("Hangi ülkeden, dinden ve yaștan olursa olsun her onurlu insan XENEIOS olma gayreti içinde olabilir. Sahip olması gereken tek vasıf, Yunanistan'a ve antiklerin güzel sanatları ve edebiyatına duyacağı tutkudur", İng. terc. N. W.).

12 Goethe, Werke 1867, c. 23, s. 270 ("bilhassa Alman eğitimi alma isteği” ve "bütün bu müktesabatı bir gün Aydınlanma ve vatanlarının selameti için kullanma arzusu", İng. terc. N. W.).

13 Bu çeviri, 1818'de Jena'da yayınlanmış olup Goethe duyduğu hayranlığı şöyle ifade ediyordu: “... wunderbar genug, wenn man das Stück in dieser Sprache und in dieser Beziehung betrachtet, so drückt es ganz eigentlich die sehnsüchtigen Gefühle eines reisenden, und verbannten Griechen aus: denn die allgemeine Sehnsucht nach dem Vaterlande ist hier unter der Sehnsucht nach Griechenland, als dem einzig menschlich gebildeten Lande, ganz spezifisch ausgedrückt” (“... muhteşem bir eser, bu dilde ve bağlamda ele alındığında bu oyun, gezgin ve sürgün bir Yunanlının hissiyatını tam anlamıyla ortaya koymaktadır: zira burada vatana duyulan o genel özlem, çok özel bir bağlamda ve insanî eğitimin bulunduğu tek ülke olan Yunanistan'a duyulan hasret şeklinde ifade edilmektedir."), İng. terc. N. W.) (krş. Irmscher, Der Dessauer Dichter 1968, s. 59; Goethe, Werke 1867, c. 23, s. 270.)

14 Philiki Etaireia hakkında bk. Vakalopoulos, Modern Yunan Tarihi 1990, s. 118-122 (Yunanca). 


\section{Yunanistan'ın Desteklenme Sebepleri}

Yukarıda belirtildiği gibi Yunanistan'a dair çeşitli şekillerde tezahür eden yoğun ilgi, Avrupalıların Yunan isyanına fiilen katılmalarına zemin hazırlamıştır. Prut'u küçük bir kuvvetle geçerek Boğdan ve Eflak halklarını Osmanlı hakimiyetine karşı ayaklanmaya çağıran Rus hizmetindeki Rum subay Alexander Ypsilantis'in (1792-1828) 6 Mart 1821'de Yunan İsyanını ilan edişi, Avrupa'nın pek çok yerinde anında destek buldu. ${ }^{15}$ Kısa süre sonra, Nisan 1821'de Mora'da bir devrim başladı. Avrupa ve Kuzey Amerika'da yayınlanan Yunanistan'la politik dayanışma bildirgeleri, yukarıda betimlenen edebî, sanatsal ve akademik Helenseverliğin sonuçlarından biriydi.

Farklı toplumsal çevrelere ve sinıflara mensup insanlar Yunanlılarla dayanışma ve destek bildirgeleri yayınladılar. Çağdaş bir gözlemci, Helenseverliğin doğuşunun ardındaki birçok sebebi şöyle kaydetmiştir:

Alle Parteien vereinigen sich in dem Interesse für die Griechen. Die Frommen werden von der Religion, die Gebildeten von den klassischen Erinnerungen, die Liberalen von der Hoffnung auf altgriechische Republiken als Vorläufer und Pflanzschulen der künftigen allgemeinen Demokratisierung, Republikanisierung Europas bewegt. ${ }^{16}$

Kuşkusuz Klasik Antik Çağ hayranlığı Helenseverlik olgusunu tek başına açıklamaya yeterli değildir; fakat bu akım politik seferberliğin doğuşunda başka faktörlerle beraber önemli bir rol oynamıştır. Bu seferberlik, Helenseverlik taraftarlarınca "bütün bilimsel ve sanatsal eğitimin doğduğu kutlu coğrafya" ${ }^{17}$ olan antik Yunan'a minnet borcunu ödemek şeklinde anlaş111yordu. Birçok Batı Avrupalı da Osmanlı hakimiyetine karşı savaşan Yunanlıları, antik Yunanlıların doğrudan torunları olarak görüyordu. Almanya'daki Helensever heyecanın temel iddiası da bu savdı. Alman filolog Carl Jakob Ludwig Iken (1789-1841) şöyle diyordu:

... waren nicht ihre [der Neugriechen] Urahnen auch unsere Väter in Ge-

15 Bu konuda ayrıntılı bir tasvir için bk. Klein, L'humanité 2000, s. 23 vd.; ve Quack-Eustathiades, Philhellenismus 1984, s. $19 \mathrm{vd}$.

16 Akt. Irmscher, Der Dessauer Dichter 1968, s. 61 “Bütün taraflar kendi ilgilerine göre Yunanistan'da birleşti. Dindarları din, tahsillileri ise klasik Yunan'a dair hafıza harekete geçirdi. Liberaller de genel olarak Avrupa'nın demokratik ve cumhuriyetçi hâle gelmesi yolunda antik Yunan cumhuriyetlerinin öncü ve beşik vazifesi görebileceği umuduyla hareketlendi”, İng. terc. N. W.).

17 Heynig, Europas Pflicht 1921, s. 9; krş. Quack-Eustathiades, Philhellenismus 1984, s. 21 ("hehren Geburtsstätte aller wissenschaftlichen und künstlerischen Bildung", İng. terc. N. W.). 
sinnung und in Ausübung der Tugend, in Worten und Werken, nicht auch unsere Ahnen in der Wissenschaft, nicht unsere Muster in der Poesie, unsere Lehrmeister in der Kunst, sind sie nicht noch jeden Augenblick Erzieher unserer Jugend, Bildner unseres Zartgefühls, Richtschnur für den Denker, Führer und Geleit dem Schriftsteller und dem Volkslehrer, Richtscheit für den Geschmack, Kompass und Leitstern im Gebiet der Wahrheit, des Wissens und Empfindens? ${ }^{18}$

"Minnet borcu" teması, başka ülkelerdeki Helensever hareketlerde de önemli rol oynamıştır. Tek bir örnek zikretmek gerekirse, Emile Claude Gaudin (doğ. 1768), 1822'de Du soulèvement des nations Chrétiennes (Hıristiyan Ulusların Başkaldırısı Üzerine) adlı eserinde bu temayı benimsemiş ve savunmuştu. Ona göre Yunan antikitesi, hayatın her veçhe ve safhasına nüfuz etmeliydi. ${ }^{19} \mathrm{Av}$ rupalıların Yunanlılara minnet borcu olduğu iddiası, Yunan Bağımsızlık Savaş1nın, Alexander Ypsilantis gibi Yunan öncülerince de bilhassa dillendirilmiştir. ${ }^{20}$

\section{Helensever Almanya}

1821'deki Yunan isyanının en önde gelen Alman destekçileri arasında Leipzigli felsefe profesörü Wilhelm Traugott Krug (1770-1842), Münihli filolog Friedrich Wilhelm Thiersch (1784-1860) ile Bavyera'nın veliaht prensi ve müstakbel kralı I. Ludwig (1786-1868) bulunuyordu. Krug, Yunanistan'daki

18 Iken, Hellenion 1822, s. 33 (“...onların [modern Yunanlıların] ataları fikirde ve erdemli davranışta, söz ve fiiliyatta bizim de ecdadımız; ilimde atalarımız, şiirde numune-i imtisâlimiz, sanatta üstadlarımız değiller mi? Bugün de her an gençlerimizin hocaları, hissiyatımızın yaratıcıları, düşünürlerin pusulası, muharrir ve hocaların rehber ve dostları, zevk-i selimimizin kıstası; hakikat, bilgi ve duygu sahasında bir pusula ve kılavuz yıldız değiller mi?”, İng. terc. N. W.). Bu konuda ayrıca krş. Quack-Eustathiades, Philhellenismus 1984, s. 37.

19 Gaudin'e göre bebekler, ilk konuşma teşebbüslerini, La Fontaine'in ustaca yeniden işlediği Ezop Masalları eşliğinde yapar. Erkek çocukları Yunan kahramanlarına tutkun, gençler de Yunan tapınak ve heykellerine hayrandır. Erişkinliğe ulaşan erkek, Yunan savaş hünerlerinden askerlik sanatını öğrenir. Devlet adamları Yunan filozofları, tarihçi ve retorikçileri tarafından eğitilir ve onlardan ilham alır. Şairler ise Yunanlı üstatlarını taklide çalışır. Nihayet, yaşlı adam son yıllarında Yunan bilgeliğinin kaynaklarında teselli ve umut bulur. Krş. Gaudin, Soulèvement 1822, s. 68 vd.

20 Ypsilantis'in 9 Temmuz 1821 tarihli Allgemeine Zeitung'da (s. 760) yayınlanan Avrupalılara çağrısında şu satırlara yer verilmektedir: "Und doch, Ihr Europäer, hat die Natur uns nicht all' ihre Gaben versagt; sie gab uns einen freundlichen Himmel, sie hat auch auf uns einen göttlichen Funken des Geistes und der Wissenschaft ausgegossen, einen Funken, unsterblich, wie die Quelle, aus der er stammt, den unsere Thyrannen zwar unterdrücken, doch nicht ganz zerstören konnten. Wir sind die Nachkommen der Männer, welche stets Eure Bewunderung erregen werden. Die alten Trümmer unserer schönen Künste sind noch der Maßßstab und das Vorbild für die Euren; der Wohllaut unserer Sprache entzückt das Ohr Eurer Gelehrten; die Einbildungskraft Eurer Dichter bildet und bereichert sich noch an den unseren. Eure Kinder bilden sich zu großen Tugenden durch das Beispiel unserer großen Männer ... [deshalb] werfet wenigstens einen Blick des Mitleides, wenn nicht des Beistandes, auf uns." ("Fakat, ey Avrupalılar, tabiat bize bütün hediyelerini vermemezlik etmedi: Bizlere güzel bir gökyüzü verdi; üzerimize akıl ve irfanın mukaddes şerarelerini saçtı. Başımızdaki zalimler, geldiği kaynak gibi ölümsüz olan bu şerareleri söndürmeye çalıştı, ancak tamamen yok edemedi. Bizler sizlerin daima hayranlığını uyandıracak olan o insanların ahfadıyız. Güzel sanatlarımızın eski harabeleri, sizin güzel sanatlarınız için hâlâ bir kıstas ve numunedir. Lisanımızın ahengi tahsillilerinizin kulaklarını mest etmekte; şairlerinizin muhayyilesi şairlerimizce inşa ve tezyin edilmektedir. Çocuklarınız, bizim büyük adamlarımızı örnek alarak yüksek meziyetler edinmektedir... [dolayısıyla] bizlere müzaheret ile atf-1 nazar etmeyecekseniz dahi hiç olmazsa merhamet gözüyle bakın.”, İng. terc. N. W.) 
durumdan, Leipzig' deki Yunan cemaatiyle kurduğu temaslar sayesinde haberdar olmuştu. Bunun üzerine Krug, 1821 yılının Paskalya öncesi Kutsal Pazar'ında Almanya'da yaşayan Yunanlılara Griechenlands Wiedergeburt (Yunanistan'ın Yeniden Doğuşu) başlıklı bir konuşma yaparak onları Yunanlılara destek vermeye çağırdı. Bu konuşmasında şunları iddia ediyordu:

Die Herrschaft der Türken in Europa kann durchaus nicht als eine rechtmäßige (legitime) angesehn werden; sie ist nur eine angemaaßte (usurpirte). Sie entstand durch einen bloßen Angriffs- und Eroberungskrieg, der nach allen gesunden, $d$. h. vernünftigen Begriffen vom Völkerrechte nie eine Herrschaft des einen Volkes über das andere rechtlich begründen kann. ${ }^{21}$

Krug'un konuşmasına alt tema olarak Yeniden Diriliş Bayramını Idrak Programı (Programm zum Auferstehungsfeste) adını verişi, onun Helenseverlik galeyanında dinî saiklerin ne kadar önemli bir rol oynadığını göstermektedir. Ona göre İsa'nın yeniden dirilmesi, Yunanistan'ın dirilişini sşmgeliyordu. ${ }^{22}$ Çağdaş Yunanlılar sadece Avrupa'ya kültür ve bilimini veren antik Yunanlıların torunları değil, aynı zamanda Avrupalıların Hıristiyan kardeşleriydi. Bu nedenle Krug, Yunanlılara hitabının sonunda "die entweihete Sophienkirche ihre Thore öffnet, um euch [Griechen] als Sieger mit dem vorgetragnen Kreuze in ihre weiten Hallen aufzunehmen" sözleriyle hayalini dile getiriyordu. ${ }^{23}$

1 Ağustos 1821 tarihli Letztes Wort über die griechische Sache: Ein Programm zum Michaelisfeste'sinde (Yunan Davası Üzerine Son Söz: Başme-

21 Krug, Griechenlands Wiedergeburt 1821, 18-19 (“Avrupa'da Türk hakimiyeti kesinlikle yasal (meşru) görülemez; bu sadece sözde (gasp edilmiş) bir hakimiyettir. Bu hakimiyet yalnızca yağma ve işgal savaşıyla kurulmuştur. Bu savaş ise hiçbir şekilde, yani milletler arası hukukun akılcı kavramlarına göre, bir halkın başka bir halk üzerindeki hakimiyetine yasal bir zemin sağlayamaz", İng. terc. N. W.).

22 Adı geçen broşürde Krug şöyle diyordu: "Die Christenheit feiert in diesen Tagen das Auferstehungsfest. Dieses schöne Fest soll uns nicht bloß an Vergangenes erinnern; es soll uns auch mahnen, daß wir stets eingedenk seien unserer höhern Abkunft und Bestimmung, daß wir unser Herz erfüllen mit den Ideen von dem, was ewig wahr und gut und schön, daß wir uns nicht nur selbst erheben von der Finsterniß zum Lichte und von der Knechtschaft zur Freiheit, sondern auch theilnehmend freuen, wenn wir gewahren, daß Andre sich so erheben. Man wird es daher nicht seltsam finden, daß der Verfasser die unlängst begonnene Wiedergeburt Griechenlands zum Thema eines Programms für das christliche Osterfest gewählet hat." ("Hıristiyan âlemi bugünlerde Yeniden Diriliş bayramını idrak ediyor. Bu güzel bayram bizlere sadece geçmişte ne olduğunu hatırlatmakla kalmamalı; şanlı aslımızı ve hedefimizi daima hatırda tutmayı, kalplerimizi ilelebet doğru, iyi ve güzel olana dair fikirlerle doldurmayı, sadece kendimizi karanlıktan aydınlığa ve esaretten hürriyete çıkarmakla kalmayıp başkalarının da bu yolda kıyam ettiğini gördüğümüzde memnun olmayı anımsatmalıdır. Dolayısıyla yazarın Hıristiyan Paskalya bayramını anma programının konusu olarak Yunanistan'ın yakın dönemde başlayan yeniden doğuşunu seçmesi şaşırtıcı değildir.” İng. terc. N. W.), aynı yerde, Vorwort [Önsöz]).

23 Aynı yerde, s. 24 kutsallığı çiğnenmiş Ayasofya Kilisesinin kapıları, önünüzde taşınan haçla birlikte sizleri [Yunanlılar] muzaffer olarak geniş salonlarına almak üzere açılır", İng. terc. N. W.). 
lek Mikail Yortusu Programı) Krug, Alman yurttaşlarını, Yunanistan'a seyahat eden gönüllüleri ve Yunanlı yoksul aileleri destekleyecek cemiyetler kurmaya teşvik ediyordu. İhtiyatlı davranarak bu yardımları "sivil yardımlar" şeklinde nitelendirmesine ve kendisinin "Yunan davasına duyduğu ilginin arkasında insanlık ve Hıristiyanlık aşk1 yatan" ${ }^{24}$ sivil bir vatandaş olduğunu 1srarla söylemesine rağmen Krug'un Almanlara yaptığ başını derde soktu. Cemiyetler kurarak gönüllü savaşçılar için para toplama çağrısı, devlet makamlarında güçlü bir olumsuz tepki uyandırdı. Buna rağmen Krug'un iki "programı" da kamuoyunda büyük akis buldu. Yazıları hızla toplumun büyük bir kesimine ulaşarak Yunanistan meselesi hakkında geniş kapsamlı bir tartışma başlattı. Sonuç olarak Almanya'da çok sayıda Helensever cemiyet kuruldu.

Krug'un ilk programından iki ay önce Tübingen Üniversitesi'nde Protestan teolojisi profesörü olan Heinrich Gottlieb Tzschirner (1778-1828), Die Sache der Griechen, die Sache Europas (Yunan Davası, Avrupa'nın Davası) başlıklı imzasız bir broşür yayınladı. Bu broşür de hüsn-i kabulle karşılandı. Aslında Almanya'daki Protestan kiliseleri Yunanlıları destekliyor ve antik Yunanlıların torunları, bilhassa da Hıristiyan din kardeşleri olarak onlara yardım ediyorlardı. Buna rağmen Roma Katolik Kilisesi Yunanlıları destekleyecek herhangi bir girişimde bulunmamıştı. Aksine Papalık temsilcisi Giovanni Antonio Benvenuti (1765-1838), Ancona limanına getirilen silahların Yunanistan'a sevkine ambargo koydurmayı başardı. Protestanların aksine Papalık, "Yunan isyanının başından sonuna kadar bu konudaki mutlak tarafsızlığını korumuştur." 25

Yunanlılara aktif destek sağlamakla iştigal eden bir başka şahsiyet de yukarıda anıldığg gibi Münih’te antik filoloji profesörü olan Friedrich Wilhelm Thiersch'di. Helenseverliği, soyadını bazı durumlarda "Thyrsios" şeklinde Yunanlaştırmaya bile yöneltmişti Thiersch'i. Sonradan Kral I. Ludwig olan Bavyera veliaht prensiyle birlikte Thiersch, Bavyera Helenseverliğinin başlıca öncülerinden olmuştur. Thiersch'i harekete geçiren hem minnet borcu düşüncesi hem

24 Aynı yazar, Letztes Wort 1821, s. 22 ("private Hilfe", "sich aus menschlicher und christlicher Liebe für die griechische Sache interessiert", İng. terc. N. W.).

25 Hofmann, Papsttum 1952, s. 20-22 ("von Anfang bis Ende der griechischen Erhebung die strenge Neutralität eingehalten", İng. terc. N. W.). 
de Hıristiyan din kardeşlerine yardım etme arzusuydu. ${ }^{26}$ Mart 1848 Devriminden önceki yasakçı siyasi atmosferde Yunanlılara yardım seferberliği düzenleyerek onların yanında savaşacak bir Alman birliği kurulması çağrısında bulundu. ${ }^{27} 2$ Haziran - 17 Eylül 1821 tarihleri arasında Augsburger Allgemeinen Zeitung'da Von der Isar (İsar'dan) başlıklı ve çok ilgi gören bir yazı dizisi neşretti. Bu makalelerde Thiersch, Klemens von Metternich'in (1773-1859) görüşlerini ve Yunan karşıtı tutumunu yansıtan Österreichische Beobachter'ine hararetle karş1 koyuyordu. Avusturya polisi Haziran 1821'de Thiersch'in bir Alman birliği oluşturma planı olduğunu fark ettikten sonra Metternich, Alman devletlerine sert bir tonla şu talimatı verdi: “dem revolutionären Spiel des Prof. Thiersch und seinen Konsorten ein Ende zu bereiten, das lächerlich sein würde, wenn es nicht verbrecherisch wäre." ${ }^{28}$ Thiersch'in planına bilhassa Prusya hükümeti şiddetle tepki gösterdi. Prusya Dışişleri Bakanı Christian Günther von Bernstorff (17691835), 15 Eylül'de bütün Prusya elçilerine bir genelge gönderdi. Metternich'in de yaptığı gibi Helensever bir birlik kurulması planlarına muhalefetini şiddetle dile getirdiği genelgede şöyle deniyordu: "Unter den Aposteln der Freiheit hat ... keiner so viel Frechheit und eine so große Verkennung seiner Pflichten und Verhältnisse an den Tag gelegt als der Professor Thiersch zu München." ${ }^{29}$

Bununla birlikte, geleceğin Kral I. Ludwig'i olan Bavyera veliaht prensi, Helensever harekete hem lafzen hem fiilen güçlü bir destek verdi. Veliaht her akşam Kitab-1 Mukaddes'in Yunanca asıl şeklini okuyor ve Homeros'un büstü odasını süslüyordu. Helenseverliği antik Yunan'a duyduğu sevginin yanı sıra, Yunanlılarla paylaştığı Hıristiyan inancından da güç alıyordu. Mesela, 1822 yazında kaleme aldığı bir şiirde şöyle diyordu:

26 Thiersch, Yunan isyanını "kutsal bir borcu çok küçük bir kısmını da olsa geri ödemek" için en iyi firsat olarak görüyordu ve bu firsat, minnetle ve can u gönülden değerlendirilmeliydi. Bu amaçla yazar, Augsburger Allgemeine Zeitung'da ilk yayımlandığında yazıdan çıkarılan Ypsilantis'in çağrısındaki Hıristiyanlık vurgusunun, çağrının sonraki basımlarında metne eklenmesini sağlamıștır (Augsburger Allgemeine Zeitung No. 263, 20 Eylül 1821, ve Ek 122, 24 Temmuz 1821, krş. Quack-Eustathiades, Philhellenismus 1984, s. 41).

27 Bu konuda bk. Vakalopoulos, Mobilisierung 2007; Klein, L'humanité 2000, s. 49-54.

28 Akt. Seidl, Bayern in Griechenland 1981, s. 55 ("Prof. Thiersch ile avanesinin devrim oyunlarına son verilmesi: zira bunlar suç sayılmazsa bile gülünçtür", İng. terc. N. W.).

29 Akt. Irmscher, Philhellenismus 1966, s. 20 (“Özgürlük havarileri arasında.... hiçbiri Münih’teki Profesör Thiersch kadar küstah ve utanmaz olmamış, hiçbiri kendi vazife ve şartlarına dair böylesine bir idraksizlik izhar etmemiştir.”, İng. terc. N. W.). 
Da, wo die Kunst der Menschen blühte,

Des Schönen, Großen Vaterland,

Wo Weisheit wurde dem Gemühte,

Die Wissenschaft einst dem Vaterland. ${ }^{30}$

Aynı şiirin başka bir kıtası ise şöyleydi:

$D a$, wo die früh sten Kirchen stehen,

Wo Paulus lehrte Christi Wort,

Da soll das Christentum vergehen,

Vertilget werden jetzt durch Mord! ${ }^{31}$

Ludwig mahkumların serbest bırakılması için bağışlarda bulunmuş; Helensever cemiyetlerin kurulmasını teşvik etmiş, Yunan savaşında yetim kalan çocukları Münih'e getirterek bakım ve eğitimlerini üstlenmişti. 1825 'te tahta çıktığı gün Yunanlılara hitap ederek onlara daha fazla yardım sözü vermişti:

Jetzt ist die Lyra verstummt, aber das kräftige Wort,

Tönt von dem Könige aus der Fülle des glühenden Herzens,

Daß sich's gestalte zur That, Griechen, zu euerem Heil. ${ }^{32}$

Yeni kral, Thiersch ile birlikte gönüllüler birliği kurulması için kampanyalar yürütüyordu. Münih’teki Yunanlı öğrencilere burs veriyor ve eğitimlerini yakından takip ediyordu. ${ }^{33}$ Thiersch in teklifi üzerine 1828 'de Salvatorkirche'yi Münih’teki Yunan cemaatine tahsis etti. ${ }^{34}$ Bavyera kralı Haziran 1826'da, güvenilir üsteğmen Carl Wilhelm von Heideck (1788-1861) başkanlığında uzman subay ve astsubaylardan oluşan bir heyeti Yunanistan'a yolladı. Sonradan ikinci oğlu Otto’yu (1815-1867) 1832 yılında bir bilimadamı zümresi, mimar ve sanatçı eşliğinde kral olarak Yunanistan'a gönderdi. Bu ekibin modern Yunan devleti üzerinde derin tesirleri olacakt1. ${ }^{35}$

30 Akt. Seidl, "Teutschland” 1992, s. 111 ("Oradır, insanın sanatlarının filizlendiği yer / Her güzellik ve asaletin atayurdu / Aklın irfana dönüştügü yer / Bir zamanlar ilim ve marifetin atayurdu.”, İng. terc. N. W.).

31 Aynı yerde (“Orada, en eski kiliselerin olduğu yerde /Pavlus'un İsa’nın sözünü öğrettiği yerde /Hıristiyanlık zeval buluyor /Yok ediliyor cinayetlerle!", İng. terc. N. W.).

32 Aynı yerde, s. 117 (“Artık lir sessiz kaldı, ama kavi söz ise /Kralın âteşîn kalbinin en derinlerinden gelmekte /Ey Yunanlılar, sizin felahınız için icraya konulsun diye.”, İng. terc. N. W.).

33 Bu konuda bk. Kotsowilis, Die griechischen Studenten 1995, s. 276.

34 Kotsowilis, Die griechische Kirche 1998.

35 Seidl, Bayern in Griechenland 1981, s. 236-238. 


\section{Lord Byron}

Yunan bağımsızlı̆ı̆ için mücadele eden Avrupalı şairler arasında George Gordon Noël Lord Byron (1788-1824) adı öne çıkar. Goethe'nin “asrın en büyük yeteneği” ${ }^{36}$ olarak gördüğü Byron'a Alphonse de Lamartine (1790-1869), Shelley, Ugo Foscolo (1778-1827), Alexander Puşkin (1799-1837), Friedrich Wilhelm Nietzsche (1844-1900), Casimir Delavigne (1793-1843) ve Victor Hugo da hayrandı. Yunan milliyetçisi şair Kostis Palamas (1859-1943) ona şu dizeleri ithaf etmiştir:

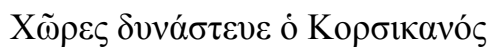

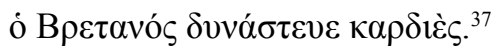

(Korsikalı ülkeleri fethetti

Şu Britanyalı ise kalpleri)

Byron, klasik Yunan edebiyatına ait eserleri daha üniversitedeyken tetkik etmiş̧i. Liberal siyasi görüşlere sahip olup Napoléon Bonaparte'ın (17691821) büyük hayranıydı. İngiltere'deki siyasi koşullardan hayal kırıklığına uğrayan Byron, 1809-1811 yılları arasında Doğu seyahatine çıktı. Childe Harold's Pilgrimage'in (Childe Harold'un Hac Seyahati) ilk kantosunu Yanya'da yazmaya başladı. Bu sırada Byron, hâlâ özgür Yunanistan hayalini şiire döken bir antik Yunan hayranıyd..$^{38}$ Daha sonra daha etkin bir Yunanperest olarak Yunanistan'a döndü. İtalya'daki devrimci Karbonari hareketinin bastırılmasıyla hayal kırıklı̆̆ına uğrayan Byron, kendine yeni bir faaliyet alanı aradı. Londra'daki Helensever cemiyetin teşvikiyle devrimci Yunanistan'a doğru yola koyularak 3 Ağustos 1823'te Argostolion'da [Argostoli] karaya çıtı. 29 Aralı'ta gemiyle Mesolongi'ye gitti ve kendi cebinden yaklaşık 500 Souliotesten ${ }^{* *}$ müteşekkil bir muharip kuvvet oluşturdu. Aynı zamanda İnebahtı'ya (Naupaktos) saldıracak donanmanın masraflarını karşılamak üzere Yunan hükümetine büyük meblağlarda para tedarik etti.

\footnotetext{
36 Eckermann, Gespräche mit Goethe 1837, s. 364 (“das größte Talent des Jahrhunderts”, İng. terc. N. W.).

37 Akt. Athanas, Şair ve Savaş̧̧ı 1974, s. 781 (Yunanca).

38 Athanas, Şair ve Savaşçı 1974, s. 781.

** Aslen Yunanistan'ın Epir bölgesinde bulunan Suli köyünün adından türeyen bu sıfat, 18. yüzyıl sonu ve 19. yüzyıl başlarında adı geçen bölgenin dağlık kesimlerinde özerk bir idare kuran; önce Tepedelenli Ali Paşa'ya isyan eden, sonra da Yunan Bağımsızlık Savaşı'na katılan, etnik olarak Arnavut kökenli Ortodoks milisler için kullanılmaktadır. 1770, 1789 ve 1803 'te olmak üzere üç defa isyan eden Sulyotlar, son isyanın başarısız olması üzerine Parga şehrine ve İyon Adalarına sürgüne gitmişlerdir. 1821'de başlayan Rum isyanı ile birlikte sürgünden dönen bir kısmı, Yunan Bağımsızlık Savaşı'nda etkin rol oynamış; Lord Byron da bu isyancılardan bir kısmını düzenli bir orduya dönüştürmeye çalışmıştır (çn)
} 
Fakat askerî hazırlıklar esnasında sıtmaya yakalanarak 19 Nisan 1824'te öldü. Yunanistan' da Byron'ın ölümü büyük bir kayıp olarak idrak edildi. Ülkenin çeşitli kentlerinde adına çok sayıda anıt dikilmiş olup günümüz Atina'sında bir cadde halen Byron adını taşımaktadır. Şairin ölüm haberi, hızla bütün Avrupa'ya yayılarak dikkatleri bir kez daha Yunan davasına çekti. İsabetli olarak kaydedildiği üzere "[j] etzt erst hatte der Philhellenismus seinen Märchenhelden, sein Idol, seinen Märtyrer."39

Helensever Alman şairler arasında öne çıkan Dessau'lu Wilhelm Müller'in (1794-1827) şairlik yeteneği Yunan bağımsızlık savaşı bağlamında yeşermiştir. ${ }^{40}$ Baskıcı siyasi atmosferde Müller'in ilham perisi, Megaira olmuştu: Amaç, Kutsal İttifakın sözcüsü olan Metternich’in, yani “Ferisilerin başı”nı yenmekti. Wilhelm Müller'in Helenseverliği neo-hümanizminden, romantizmden, ama her şeyden önce liberal siyasi görüşlerinden ileri geliyordu. Ona göre Yunan özgürlüğüne methiyeler düzmek, Almanların kendi özgürlük arzularını ifade etmenin en iyi yoluydu.

\section{Avrupa Helenseverliği}

Dönemin Helensever hareketinde İsviçreli banker Jean Gabriel Eynard (1775-1863) gibi finansörler de yerlerini almıştı. ${ }^{41}$ 1822-1827 arasında Cenevre' de yaşadığı sırada usanmadan anayurdunun davası için çalışan eski Rus Dışişleri Bakanı Kont Kapodistrias, Eynard'ı Yunan davasına kazandırmayı başarmıştı. ${ }^{42}$ Bundan sonra Avrupalı Helensever ağını kontrolüne alan Eynard, Avrupa' daki tüm Helensever cemiyetler tarafından, hareketin ikinci evresindeki kilit kişi olarak görülüyordu. Eynard, Yunanistan'a büyük miktarda para, silah, cephane, erzak ve ilaç gönderdi ${ }^{43}$ ve Avrupa Helensever cemiyetlerinin para toplama faaliyetlerini koordine etti. Ayrıca Cenevreli yoldaşı François Marcet ile İngiliz William Romilly'i muhbir olarak Yunanistan'a gönderdi. ${ }^{44}$

39 Seidl, Bayern in Griechenland 1981, s. 67-68 (“Artık Helenseverliğin bir efsanevi kahramanı, idolü ve şehidi vardı”, İng. terc. N. W.).

40 Irmscher, Der Dessauer Dichter 1968, s. 48.

41 Bu konuda bk. Choisy, Suisse et Grèce 1907, s. 10.

42 Bu konuda bk. Vakalopoulos, Băglar 1975, ss. 32 vd. (Yunanca).

43 Speliades, Hatıralar 1972, s. 569 (Yunanca); Vakalopoulos, Bağlar 1975, s. $42-44$ (Yunanca).

44 Aynı yerde, s. 37 vd. (Yunanca); bu konuda önemli bir tartışma da şu kaynakta bulunmaktadır, Simopoulos, Devrimci Yunanistan 2004, s. 85-91 (Yunanca). 
Mesolongi Kuşatmasında kentin savunulmasına desteklerinden dola$\mathrm{y}^{45}$ Yunan hükümeti onu Yunanistan'ın büyük dostu ve bir "velinimet"46 olarak övüyordu. Başka Helenseverlerde olduğu gibi Eynard'ın Helenseverliğinde de Hıristiyan inancının ve neo-hümanist eğitim ideallerinin payı vardı. Ancak Eynard'da muhtemelen -bağımsız Yunanistan'la ticari bağların kurulması gibiekonomik nedenler de rol oynamıştır. Onun ilk Yunan bankasının kurucu ortaklarından oluşu da bu iddiayı destekler niteliktedir. ${ }^{47}$

Helensever hissiyata sahip en önemli Avrupalı politikacılar, Fransız d1şişleri bakanı Chateaubriand ve İngiliz mevkidaşı George Canning (1770-1827) idi. Chateaubriand'ın Helenseverliği bazen romantizm, bazen de liberalizmden kaynaklanırken; Canning'in çağdaş Yunanistan'a ilgisi liberal siyasi görüşleriyle ilişkiliydi. Chateaubriand 1825 'te hazırladığı bir broşürle Yunan davasına destek verdi. 28 Mayıs 1826'da Courrier du Léman'in editörü Charles Durand'a, "Her ne olursa olsun bir Yunanlı olarak ölmek isterim"48 diye yazıyordu.

Sayısız edebiyat ve sanat eserine yansiyan Avrupalı Helensever haletiruhiye, müziği de etkilemiştir. Yunanlıların bağımsızlıkları için kahramanca verdikleri mücadele, sanatsal ifadesini vals, opera ve müzikli komedi formlarında bulmuştu. ${ }^{49} \mathrm{Me}-$ sela, Gioachino Antonio Rossini'nin (1792-1868) L'assedio di Corinto'su (1826), Mesolongi kuşatması ve imhasına allegorik bir atıftı. Hector Berlioz'nun (18031869) ilk kez 1828 'de sahnelenen operası La Révolution grecque: Scène héroïque'de Yunan bağımsızlık mücadelesi soylu ve yüce bir devrim olarak tasvir ediliyordu. Ludwig van Beethoven'nn (1770-1827), August von Kotzebue'nun (1761-1819) bir oyunu için yazdı̆̆ sahne müziği Die Ruinen von Athen [Atina Harabeleri] (op. 113, ilk icrası 1812) da güçlü Helensever tınılara sahipti.

\section{Yunanlılara Yardım Cemiyetleri}

Helensever faaliyetlerin en önemli şekli, kuşkusuz Helensever cemiyetlerin kurulması olmuştur. Bu cemiyetler, Yunanlılara çeşitli yollarla destek vermek

45 Bu konuda bk. Koukkou, Jean Gabriel Eynard 1963, s. 9 (Yunanca); Vakalopoulos, Bağlar 1975, s. 42 vd. (Yunanca). 46 Aynı yerde, s. 52 vd. (Yunanca).

47 Bu konuda bk. Simopoulos, Devrimci Yunanistan 2004, s. 85, not 1 (Yunanca); Kominos, Otto ve Ulusal Banka 1969 (Yunanca).

48 Documents 1826, s. 56-58. Ayrıca krş. Amandry, Fransız Seramiklerinde Yunan Devrimi 1982, s. 23 (Yunanca).

49 Krş. Hess, Agazzi \& Décultot, Vorwort 2009, s. XII. 
için gereken sermayeyi bağış ve yardımlarla topluyordu. İlk Helensever cemiyet, Wilhelm Krug'un halka hitap edişinden hemen sonra 1821 Ağustos'unda Stuttgart'ta kuruldu. Bir ay sonra Darmstadt'ta bir Yunan cemiyeti kuruldu. 1821 sonuna gelindiğinde güneybatı Almanya ve İsviçre'de çok sayıda Helensever cemiyet kurulmuştu. Kasım 1821'de Zürih'de resmî adı “Zürcherischer Hülfsverein für die Griechen" olan Helensever bir cemiyet kurulması, Yunanlılara yardımın koordine edilmesi açısından bilhassa önemliydi. Bundan kısa süre sonra Almanya ve İsviçre'de başka birçok Helensever cemiyet kuruldu.

İngiltere'de Helenseverlik faaliyetleri başlarda şahsî ve gayrı resmî bir nitelik taşıyordu. Fakat Sakız Adası'ndaki katliam Helenseverlerin faaliyetlerini arttırmalarına neden oldu. Böylece 1823'te Londra' da Yunan Komitesi [The Greek Committee] kuruldu. Fransa'da kurulan "Société de la Morale Chrétienne" [Hiristiyan Ahlâkı Cemiyeti] adlı insanî yardım cemiyeti ise Yunanlılara insanî yardım sağlamayı amaçlyyordu. Bunun ardından 1824'te "Société philanthropique en faveur des Grecs" [Yunanlllara Destek Hayırseverlik Cemiyeti] adlı bir Helensever bir cemiyet kuruldu. Bu cemiyetin faaliyetleri Yunanlı isyancılara doğrudan yardım sağlamaktan ibaretti. Yunan Bağımsızlık Savaşı sırasında, 1821-1827 arasındaki dönemde, İtalya, Belçika, İsveç, Hollanda, İspanya ve Rusya gibi başka Avrupa ülkelerinde de Helensever cemiyetler kuruldu. Başkan James Monroe'nun (1758-1831) 1823'te Yunan bağımsızlık mücadelesini resmen onayladığını ilan etmesi, Amerikan Helensever hareketi için bilhassa önemliydi. Bilahare Boston, New York, Philadelphia ve başka yerlerde de Helensever cemiyetler kuruldu.

Bütün bu cemiyetler, Yunan bağımsızlık mücadelesini desteklemek için çeşitli faaliyetler düzenlediler. Yunanistan'a silah, cephane, erzak, giyecek sevkiyatı ile başka türden yardımları finanse ettiler. Sanat sergileri düzenlendi; savaştaki önemli olayları tasvir eden ve hasılatları Yunanlılara yardım olarak gönderilen taşbaskı resimler çok miktarda basılarak satıldı; kişisel ziynet eşyaları Yunanistan temalarıyla süslendi ve Yunan bayrakları üretilerek Yunanlı isyancılara gönderildi. Helenseverliğe yardım amaçlı çok sayıda müzayede yapılıyor; ölen savaşçıların veya zulme uğramış Yunanlı bakirelerin resimlerin taşıyan tabak takımları, şarap şişeleri, çiçekli vazolar, nakışlı elbiseler, kadın yelpazeleri, saatler, mürekkep 
hokkaları ve mücevher kutuları satıliyordu. ${ }^{50}$ Hatta bir Alman pastacı, Helensever şarkıların sözleriyle bezeli pastalar satıyordu. ${ }^{51}$ Yunan bağımsızlık mücadelesi Eugène Delacroix (1798-1863), Horace Emile Jean Vernet (1789-1863), JacquesLouis David (1748-1825), Antoine-Jean Gros (1771-1835) gibi ressam ve heykeltraşlar ile Delavigne, Pierre-Jean de Beranger (1780-1857) ve Victor Hugo gibi şairler için de gözde bir ilham kaynağı olmuştu.

Bununla birlikte Helensever cemiyetlerin esas faaliyeti, Yunanlılarla yan yana savaşacağ farz edilen gönüllüleri desteklemekti. Avrupa hükümetlerinin olumsuz tutumuna rağmen birçok Avrupalı, Yunan Bağımsızlık Savaşının başlamasından sonra savaşa katılmak maksadıyla Yunanistan'a gitmek istiyordu. $\mathrm{Bu}$ insanlar, kendi ülkelerindeki siyasi şartlardan memnun olmayan genç öğrenciler ve liberal idealistler, Napoléon Savaşlarının bitmesinin ardından kendilerine yeni bir faaliyet sahası arayan subayların yanı sıra maceracılar, topluma uyum sağlayamayanlar ve kanun kaçaklarından oluşuyordu. Bu sebeple bu yardımlar tartışma yaratmıyor da değildi. Gönüllülerin çoğu Yunan isyanının ilk yıllarında (Ekim 1821 ile Kasım 1822 arasında) Yunanistan'a gittiler. Almanya ve İsviçre'deki Helensever cemiyetler, Yunanistan'a dokuz gönüllü seferi düzenledi. Aralarında Fransızlar (71), İtalyanlar (62), İsviçreliler (19) ve İngilizler (12) de bulunmasına rağmen bu dönemdeki gönüllülerin çoğu (265) Almandı. Bunun yanında az say1da Polonyalı ve Amerikalı da seferlere katılmıştı. ${ }^{52}$

Profesör Thiersch'in Alman birliği kurma planı bu bağlamda özel bir ilgiyi hak etmektedir. Thiersch planını gerçekleştirmek için Theokharis Kephalas gibi Yunan yurtseverlerle temasa geçti. Bunun sonucunda kurulan Alman birliği 130 adamdan oluşuyordu. Ancak Thiersch'in sadece askerî eğitimli kişilerin alınması yönündeki kesin talimatına rağmen bunların çoğu herhangi bir askerî eğitim görmemişti. Birlik Kasım 1822'de Yunanistan'a ulaştı. Bu, anılan süre zarfinda gerçekleştirilen dokuzuncu ve son seferdi. Birliğe bağlanan büyük umutlara rağmen bu sefer, maksadına ulaşmamış ve Yunanistan'a varışından birkaç hafta sonra dağılmıştır. ${ }^{53}$

50 Bu konuda daha ayrıntılı bir tartışma için bk. Tsigaku, Glanz der Ruinen 1995, s. 20-21.

51 Tsigaku, Glanz der Ruinen 1995, s. 21.

52 Bk. St. Clair, Greece 1972, s. 356, akt. Quack-Eustathiadis, Philhellenismus 1984, s. 55. Gerhard Grimm tüm dönemdeki gönüllü sayısının 800 ilâ 1200 arasında olduğunu tahmin etmektedir. Grimm, Studien zum Philhellenismus 1965, ss. 41, 46; ayrica bk. Klein, L'humanité 2000, s. 53, 128 no'lu not.

53 Bu konuda bk. Quack-Eustathiadis, Philhellenismus 1984, s. 52-54; Vakalopoulos, Mobilisierung 2007; Klein, L'humanité 2000, s. 37-39, 266-267. 
Gönüllü seferlerinin yanı sıra Helensever cemiyetler ayrıca Avrupa ve Rusya’ya gelen Yunanlı sığınmacılara da yardım sağlıyordu. Örneğin Alexander Ypsilantis'in kuvvetlerinin bir kısım bakayası Rusya üzerinden İsviçre'ye kaçarak, buradaki Helenseverlerin yardımlarıyla, Marsilya üzerinden yeniden Yunan cephesine nakledilmişti. ${ }^{54}$ Başka Yunanlılar da savaşın neden olduğu karışıklıklardan kurtulmak için Ancona'ya kaçmıştı. Helensever cemiyetlerin yardımını göremeyen bu insanlara Papalık devletinin organları yardım eli uzattı. Yaklaşık 52.000 kişiden oluşan bir diğer büyük Yunanlı sı ğınmacı topluluğu ise Odessa ve Basarabya'ya ulaştı. Bunlar İstanbul'dan ve Tuna eyaletlerinden geliyordu. Bu mültecilere de devletin resmî kurumları ve kilise yardım etti.

Trieste, Ancona, Livorno, Odessa, Marsilya, Malta, Amsterdam ve Viyana'da sığınmacılara destek cemiyetleri kuruldu. Yukarıda anılan Fransız hayır cemiyeti "Société de la Morale Chrétienne", Yunan sığınmacılara yardım için Mart 1823'te "Comité en faveur des Grecs réfugiés en France" [Fransa'ya İltica Etmiş Yunanlılara Destek Komitesi] adlı bir alt dernek kurdu.

Helenseverlerin faaliyetleri, Avrupa'da ve başka ülkelerdeki iklimi Yunanlıların lehine değiştirdi. Helensever hareket, Helenseverlik coşkusunu besleyip sürdürmüş ve Yunan Bağımsızlık Savaşının nihai muharebesinin yaşandığ 1 Navarin'de 1827 'de yaşanan olayları belirli ölçüde etkilemiştir. O dönemde de denildiği gibi, "Navarino ist ein Triumph des Philhellenismus, ein Sieg der Völker über die Politiker" ${ }^{55}$ Tek sebep olmasa bile Helenseverlik hareketinin Yunan isyanının başarıya ulaşmasına önemli bir katkı sağladığı kesindir.

\section{Bavyera'daki "Devlet Helenseverliğì"}

Bavyeralı Wittelsbach Hanedanı'nın (1833-1862) himayesi altında modern Yunan devletinin kurulması koşulları üzerinde 1827-1832 Londra Konferansında uzlaşma sağlandıktan sonra Avrupa Helenseverliği yeni bir evreye girmiş ve hükümet tarafindan yönlendirilip desteklenen bir tür "devlet Helenseverliği"ne ${ }^{56}$ dönüşmüştür. I. Otto döneminde Bavyera Hanedanı'nı bekleyen tek görev, Bağımsızlık Savaşı ve İç Savaşın yarattığı kargaşa sonrası istikrarlı bir siyasi önderlik ve hükümet kurma görevi değildi. Yunanistan'daki Otto idaresi, yoksul ve geri kalmış bir ülke için kapsamlı bir “yenilenme” süreci

54 Klein, L'humanité 2000, s. 38-39.

55 Seidel, Bayern in Griechenland 1981, s. 78 ("Navarin Helenseverliğin zaferi, halkların politikacıları mağlup etmesidir", İng. terc. N. W.).

56 Krş. Spaenle, Philhellenismus in Bayern 1990 
de başlatmak zorundaydı: Yunanistan'ı Batı Avrupa'nın kültürel standartlarına ulaştırmayı ve ülkenin Avrupa'yla entegrasyonunu kolaylaştırmayı hedefleyen bu girişimler, Bavyera devletinin sağlayacağı kalkınma yardımlarıyla desteklenecekti. ${ }^{57}$ Böylece ulus-devlet oluşum süreci kaçınılmaz bir şekilde monarşistotoriter bir modernleşme programının tuzağına düştü. Otto’nun tahta çıkmasına (1835) kadar devlet işlerini yöneten Naiplik İdaresi, Devlet Müsteşarı ve Bakan1 Joseph Ludwig Graf von Armansperg (1787-1853), Devlet ve İmparatorluk Müsteşarı ve Fransız hukuku profesörü Georg Ludwig von Maurer (17901872) ile General Karl Friedrich von Heideck’ten (1788-1861) oluşuyordu. Naiplik İdaresi ilk aşamada işleyen bir merkezî devlet aygıtı kurmayı başarsa $\mathrm{da}^{58}$ Bavyeralıların bir Yunan "ulusu kurma" girişimleri en nihayetinde başarıya ulaşamad1. Gerek Bavyera devlet bürokrasisinin modernleşmeye karşı devletçi yaklaşımı, gerekse Otto idaresinin cumhuriyet karşıtı monarşizmi nedeniyle modernleşmeciler -her ne kadar Helensever hissiyatla hareket etseler de- Yunan halkı tarafindan fazla sevilmedi. 1843' deki ulusal anayasa kongresini kabul etmek zorunda kalan Otto, nihayet 1862 yilında tahtan feragat etti.

Bavyera kralı I. Ludwig' in tutkulu Helenseverliği sayesinde Atina'nın yeni Yunan devletinin başkenti ve monarşinin payitahtı olmasının ardından kentin mimari yenilenme süreci başladı. Otto idaresinin ilk on yıllık döneminde yeni Atina için birkaç plan hazırlanmıştı. Bu planlardan bazıları kısmen hayata geçirilirken bir kısmı sadece kâğıt üzerinde kalmıştı. ${ }^{59}$ I. Ludwig, kendi kraliyet mimarı olan romantik klasist Leo von Klenze'yi (1784-1864) Atina'ya gönderdi. Antik Çağ sonrasına ait tüm unsurların Akropolis'ten uzaklaştırılması ve yapıların restorasyonuna başlanması büyük ölçüde Klenze'nin çalışmalarıyla gerçekleştirilmiştir. Klenze, kent için tasarlanan ilk planlar üzerinde yeniden çalışarak bir dizi kamu binası tasarladı. Friedrich von Gärtner (1792-1847) mimari planlarını uygulamaya koymada Klenze'ye göre daha başarılı oldu. Atina'da bugün Parlamentoya ev sahipliği yapan kral konutu Gärtner'in planlarına göre inşa edilmiştir. Karl Friedrich Schinkel'in (1781-1841) öğrencileri olan Stamatis Kleanthis (1802-1862) ve Eduard Schaubert (1804-1860) adlı mimarlar, yeni Atina ve Pire kentleri için ilk planları hazırladılar. Arkeolog Ludwig Ross (1806-

57 Krş. Maras, Philhellenismus 2012.

58 Dickopf, Georg Ludwig von Maurer 2002; krş. Dickopf, Die bayerische Regentschaft 1995; Grimm \& Nikolaou, Bayerns Philhellenismus 1993; Institute for Balkan Studies, Der Philhellenismus 1986.

59 Krş. Papageorgiou-Venetas, Hauptstadt Athen 2002. 
1859) ile birlikte çalışan mimar Hans Christian Hansen Schaubert (1803-1883) Akropolis'teki Athena Nike Tapınağı'nın restorasyonunu yönetti. Alman klasizminin önde gelen siması Karl Friedrich Schinkel, yeni kurulan Yunan başkentini hiç ziyaret etmemesine rağmen Akropolis’teki kraliyet sarayının planlarını hazırlad1. ${ }^{60}$ Ancak bu Akropolis'in tamamen dönüşmesine neden olacağından, Klenze bu planı kabul etmedi. Öte yandan Bavyera Helenseverliğinin Münih’in görünümü üzerinde de önemli etkisi olmuştur. Söz gelişi Königsplatz, Karl von Fischer (1782-1820) tarafından Akropolis model alınarak tasarlanmıştır.

\section{Jakob Philip Fallmerayer ve Helenseverlik Karşıtlığı}

Tüm bunlara rağmen Avrupalıların Yunanistan coşkusu ve klasistlerin antik Yunan'ı idealleştirmesi muhalifsiz kalmış da değildir. Ne gariptir ki Yunanperestlerin kafasındaki Yunanistan imgesine ve onunla ilişkili tüm ideal ve tasavvurlara yönelik hücumlar, Metternich'in egemen olduğu karşı devrimci Restorasyon döneminin simgelediği birinden değil, 1848 Devriminde etkin rol oynamış ve sonuç olarak Münih Üniversitesi'ndeki profesörlüğünü kaybetmiş birinden, yani Jakob Philipp Fallmerayer'den (1790-1861) gelmiştir. ${ }^{61}$ Fallmerayer, dünya tarihinin dönemlerinin, bu dönemlerde egemen olan 1rklarca belirlendiği tezinden hareketle, modern Yunanlıları tanımlayan unsurun dilsel kimliklerinden çok ait oldukları Slav ırkı olduğunu düşünüyordu. 6. ve 7. asırlardaki Slav göçleri ve Arnavutların yayılması göz önüne alındığında Yunan ırkının Antik Çağdan beri varlığını sürdürdüğü varsayımının çok tartışmalı olduğunu iddia ediyordu. ${ }^{62}$ Fallmerayer'in modern Yunanlıların ulusal kimliğini kabul etmemesi, bir dizi reddiye ve karşı iddiayı tetikledi. Batı Avrupalı Yunanperestlerin Fallmerayer'in iddiasına karşı koymak ve antik Yunanlılarla modern Yunanlılar arasında kültürel-tarihsel ve ulusal süreklilik olduğu tezini desteklemek üzere ileri sürdükleri tüm iddialar, 19. yüzyılda Yunan tarihyazımınca benimsenmiş olup o zamandan beri Yunanlıların devlet ve toplum anlayışlarının özünü oluşturmaktadır. ${ }^{63}$

\section{Evengelos Konstantinu, Frankfurt}

60 Krş. Fountoulakis, Stamatis Kleanthes und Eduard Schaubert 2006.

61 Krş. Thurnher, Jakob Philipp Fallmerayer 1993.

62 Krş. Fallmerayer, Geschichte der Halbinsel Morea 1830.

63 Krş. Speck, Philhellenismus 1994. 


\section{Kaynakça}

Documents relatifs à l'état présent de la Grèce. Publiés d'après les communications du Comité philhellénique de Paris, 1. Kitap, Paris 1826.

Eckermann, Johann Peter: Gespräche mit Goethe in den letzten Jahren seines Lebens: 18231832: Erster Theil, 2. Bask1, Leipzig 1837.

Fallmerayer, Philipp Jakob: Geschichte der Halbinsel Morea während des Mittelalters, Stuttgart 1830, online: http://nbn-resolving.de/urn:nbn:de:bvb:12-bsb10447159-7 [21/11/2012].

Gaudin, Emile Claude: Du soulèvement des nations Chrétiennes dans la Turquie européenne, Paris 1822.

Goethe, Johann Wolfgang von: Iphigenia in Tauris, Liverpool 1851, online: http://archive.org/ stream/iphigen00goet [21/12/2012].

Goethe, Johann Wolfgang von: Werke: Auswahl, Stuttgart 1867, C. 1-36.

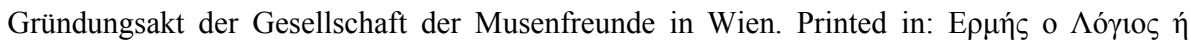

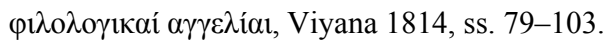

Heynig, Johann Gottlob: Europas Pflicht, die Türken wieder nach Asien zu treiben, und Griechenland mit unserer christlichen Welt zu vereinigen, Dessau 1821.

Hofmann, Georg: Das Papsttum und der griechische Freiheitskampf(1821-1822): Quellenausgabe mit Einführung, Rome 1952.

Iken, Carl: Hellenion: Über Cultur, Geschichte und Literatur der Neugriechen, Leipzig 1822, 1. Heft.

Krug, Wilhelm Traugott: Griechenlands Wiedergeburt: Ein Programm zum Auferstehungsfeste, Leipzig 1821, online: http://www.mdz-nbn-resolving.de/urn/resolver. pl?urn=urn:nbn:de:bvb:12-bsb10446862-1 [21/11/2012].

Krug, Wilhelm Traugott: Letztes Wort über die griechische Sache: Ein Programm zum Michaelisfeste, Frankfurt am Main 1821.

Schlegel, Friedrich: Kritische Friedrich-Schlegel-Ausgabe, ed. by Ernst Behler v.d., Paderborn 1967, vol. 2.

Thiersch, Friedrich Wilhelm: "Von der Isar" başlıklı yazı dizisi, Augsburger Allgemeine Zeitung (AAZtg) içinde, 1821.

Winckelmann, Johannes Joachim: Gedanken über die Nachahmung der griechischen Werke in der Malerey und Bildhauerkunst, Dresden 1755, 2. Bask1, 1756, online: http://www. archive.org/details/gedankenuberdie00winc [21/11/2012]. 


\section{Kaynakça}

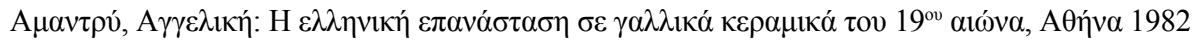
[Amandry, Angeliki: 19. Yüzyll Fransız Seramiklerinde Yunan Devrimi, Atina 1982].

Arnold, Robert: Der deutsche Philhellenismus: Kultur- und literarhistorische Studie Bayreuth 1896 (Euphorion Özel Baskıs1, 2. İlâve Kitap, Bamberg 1896, ss. 71-181).

Arsh, Gregory L.: The Russian State Philhellenism of the XVIII Century: From Peter the Great to Catherine the Great, Frankfurt am Main 2007, Philhellenische Studien 13 (2007) içinde, ss. 83-87.

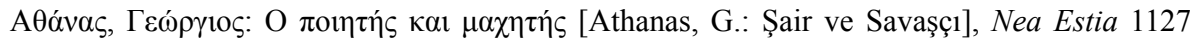
(1974) içinde, ss. 772-785.

Beiser, Frederick C. (ed.): The Early Political Writings of the German Romantics, Cambridge 1999.

Choisy, Frank: Suisse et Grèce, Atina 1907.

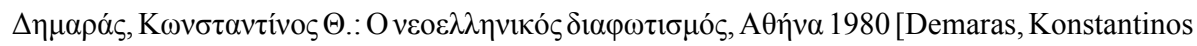
Th.: Modern Yunan Aydınlanması 2. Bask1, Atina 1980].

Dickopf, Karl: Georg Ludwig von Maurer und seine juristische Tätigkeit in Griechenland (Februar 1833-Juli 1834), Alexander Papageorgiou-Venetas (ed.): Das Ottonische Griechenland: Aspekte der Staatswerdung içinde, Atina 2002, ss. 143-152.

Dickopf, Karl: Die bayerische Regentschaft in Griechenland (1833-1835), Reinhard Heydenreuter v.d. (ed.): Die erträumte Nation: Griechenlands Wiedergeburt im 19. Jahrhundert, Münih 1995, ss. 83-97.

Fountoulakis, Olga: Stamatis Kleanthes und Eduard Schaubert: Zwei Schinkelschüler in Griechenland: Biographische Skizzen der beiden Architekten und ihre grundsätzliche Bedeutung für das moderne Griechenland, PHILIA: Eine Zeitschrift für Europa I (2006) içinde, ss. 20-27.

Grimm, Gerhard: Studien zum Philhellenismus, Habilitationsschrift, Ludwig-MaximilianUniversität Munich 1965 (yayınlanmamış).

Grimm, Gerhard \& Nikolaou, Theodor (ed.): Bayerns Philhellenismus: Symposium an der Ludwig-Maximilians-Universität München am 22. und 23. Kasım 1991, Münih 1993.

Hess, Gilbert; Agazzi, Elena \& Décultot, Elisabeth: Vorwort, Gilbert Hess, Elena Agazzi \& Elisabeth Décultot (ed.): Graecomania: Der europäische Philhellenismus içinde, Berlin 2009.

Institute for Balkan Studies (ed.): Der Philhellenismus und die Modernisierung in Griechenland und Deutschland: Erstes Symposium organisiert in Thessaloniki und Volos (am 7.-10. 
März 1985) vom Institut für Balkan-Studien und der Südosteuropa-Gesellschaft Munich, Selanik 1986.

Irmscher, Johannes: Der Dessauer Dichter Wilhelm Müller und der deutsche Philhellenismus, Hellenika 21 (1968) içinde, ss. 48-74.

Irmscher, Johannes: Der Philhellenismus in Preußen als Forschungsanliegen, Berlin 1966.

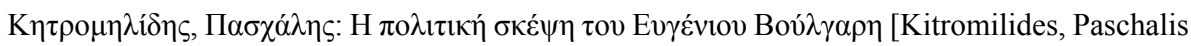
M.: Eugenios Voulgaris 'in Siyasi Görüşleri], G. S. Henrich (ed.): Evgenios Vulgaris und die neugriechische Aufklärung in Leipzig: Beiträge der Konferenz an der Universität Leipzig, Institut für Klassische Philologie, Abteilung Byzantinische und Neugriechische Philologie, 16-18 Ekim 1996, Leipzig 2003, ss. 83-96.

Klein, Natalie: L'humanité, le christianisme, et la liberté: Die internationale philhellenische Vereinsbewegung der 1820er Jahre, Mainz 2000.

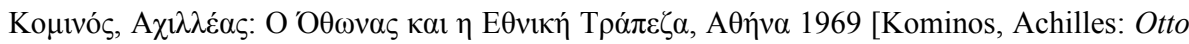
ve Ulusal Banka, Atina 1969].

Korhonen, Tua: Der frühe Philhellenismus und die griechische Tradition im Finnland des 17. und 18. Jahrhunderts, Philhellenische Studien 13 (2007) içinde, ss. 61-67.

Kotsowilis, Konstantin: Die griechische Kirche in München: Als Gotteshaus zum Erlöser, Gemeinde der Hellenen und Mittelpunkt des bayrischen Philhellenismus, 4. baskı, Münih 1998.

Kotsowilis, Konstantin: Die griechischen Studenten in München unter König Ludwig I. von Bayern (von 1826 bis 1844): Werdegang und späteres Wirken beim Wiederaufbau Griechenlands, Münih 1995.

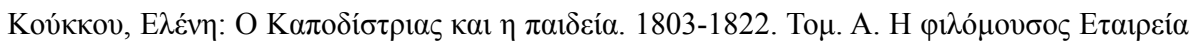

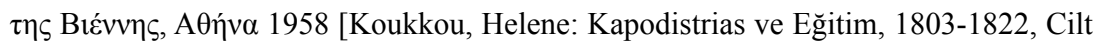
A: Viyana'da İlham Perileri Dostları Cemiyeti, Atina 1958].

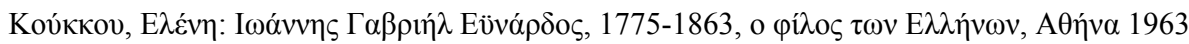
[Koukkou, Helene: Jean Gabriel Eynard, Yunanlıların Dostu, Atina 1963].

Maras, Konstadinos: Philhellenismus: Eine Frühform europäischer Integration, Würzburg 2012.

Papageorgiou-Venetas, Alexander: Hauptstadt Athen: Zur Planungsgeschichte der Neugründung der Stadt im 19. Jahrhundert, in: Alexander Papageorgiou-Venetas (ed.): Das Ottonische Griechenland: Aspekte der Staatswerdung, Athens 2002, ss. 277-300.

Pfeiffer, Gerhard: Studien zur Frühphase des europäischen Philhellenismus (1453-1750), Erlangen-Nuremberg 1968.

Quack-Eustathiades, Regine: Der deutsche Philhellenismus während des griechischen Freiheitskampfes 1821-1827, Münih 1984. 
Seidl, Wolf: Bayern in Griechenland: Die Geburt des griechischen Nationalstaats und die Regierung König Ottos, Münih 1981.

Seidl, Wolf: Das Land der Griechen mit der Seele suchend: Über das Griechenlandbild der deutschen Klassik, in: Philhellenische Studien 1 (1989), ss. 15-37.

Seidl, Wolf: "Der Teutschland half, wird Hellas retten": Ludwig I. von Bayern als philhellenischer Dichter, Philhellenische Studien 2 (1992) içinde, ss. 111-119.

$\Sigma \mu$ ó Kyriakos: Yabancıların Gözüyle Devrimci Yunanistan (1821), C. 5, Atina 2004].

Spaenle, Ludwig: Der Philhellenismus in Bayern 1821-1832, Münih 1990.

Speck, Paul: Schlecht geordnete Gedanken zum Philhellenismus, in: Alfred Noe (ed.): Der Philhellenismus in der westeuropäischen Literatur 1780-1830, Amsterdam 1994, ss. 1-17.

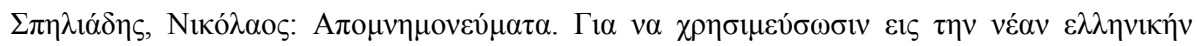

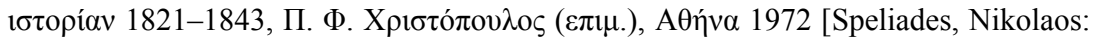
Hatıralar, ed. P. Ph. Christopoulou, Atina 1972].

St. Clair, William: That Greece Might Still Be Free: The Philhellenes in the War of Independence, Londra 1972.

Thurnher, Eugen (ed.): Jakob Philipp Fallmerayer: Wissenschaftler, Politiker, Schriftsteller, Innsbruck 1993 (Schlem-Schriften 202).

Tsigaku, Fani-Maria: Glanz der Ruinen: Die Wiederentdeckung Griechenlands in Gemälden des 19. Jahrhunderts: Aus den Beständen des Benaki Museums, Athen und des Rheinischen Landesmuseums Bonn, Köln 1995.

Vakalopoulos, Konstantinos A.: Die Mobilisierung der europäischen philhellenischen Vereine zur Aufstellung der deutschen Legion während des griechischen Freiheitskampfes, Philhellenische Studien 13 (2007) içinde, ss. 323-329.

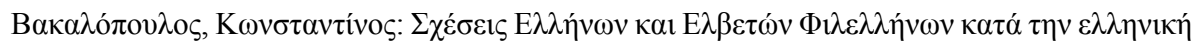

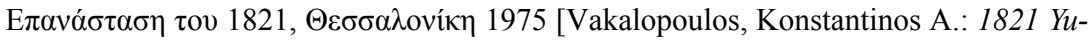
nan Devrimi Esnasında Yunanlılarla İsviçreli Helenseverler Arasındaki Bağlar, Thessaloniki 1975].

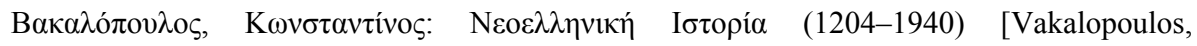
Konstantinos A.: Modern Yunan Tarihi (1204-1940), Thessaloniki 1990].

Wünsche, Raimund: Carl Haller von Hallerstein: Der erste deutsche Philhellene in Griechenland, Philhellenische Studien 9 (2003) içinde, ss. 199-235. 